\title{
Adrenal involvement in the diabetes-induced loss of growth hormone and prolactin receptors in the livers of female rats
}

\author{
J. M. Bryson and R.C. Baxter \\ Department of Endocrinology, Royal Prince Alfred Hospital, and Department of Medicine, University of Sydney, \\ Sydney, New South Wales, Australia
}

\begin{abstract}
Summary. Streptozotocin-induced diabetes causes a decrease in growth hormone and prolactin receptors in the livers of female rats, and in the serum concentration of somatomedin-C/ insulin-like growth factor-I, concomitantly with an increase in the serum testosterone levels. In this study, a possible role for adrenal androgens in the loss of receptors was examined. Rats were adrenalectomised bilaterally 3 days after the induction of diabetes with streptozotocin ( $100 \mathrm{mg} / \mathrm{kg}$ intravenously), and livers were removed 3 days later. Adrenalectomy had no effect on binding of ovine prolactin or bovine growth hormone to liver microsomal membranes from non-diabetic rats, but in diabetic rats it entirely abolished the $56 \%$ decrease in prolactin binding and significantly reversed the $66 \%$ decrease in growth hormone binding and the parallel fall in serum levels of somatomedin-C/insulin-like growth factor-I $(p<0.05)$. Adrenalectomy also prevented the diabetes-induced rise in serum testosterone. Daily injection of testosterone to normal and diabetic rats for 12 days significantly reduced both prolactin and growth hormone binding $(p<0.001)$, with the effect
\end{abstract}

We have previously reported that both growth hormone $(\mathrm{GH})$ and prolactin (PRL) receptors in liver microsomal membranes decreased in number, but not affinity, in female rats with experimental diabetes induced by streptozotocin $[1,2]$. Insulin treatment restored these receptors to normal levels. The circulating level of the GH-dependent growth factor somatomedin-C (identical to insulin-like growth factor-I [3] and designated SM-C/IGF-I) also decreases in experimental diabetes [4]. It has been suggested that the loss of GH receptors might be associated with the decrease in SM-C/IGF-I, although there is some evidence that the growth factor and receptor levels fall at different rates [5]. In an earlier study, we observed that the loss of PRL receptors in diabetes was accompanied by an increase in serum testosterone, which returned to normal levels with insulin treatment [2]. Subsequently Leaming et al. [6], investigating steroid metabolism in female rats made diabetic with alloxan or streptozotocin, confirmed that diabetes increased testosterone levels. Whereas ovariectomy had of diabetes being additive upon the testosterone effect. Implantation of testosterone-filled silastic capsules at the time of adrenalectomy (i.e. for 3 days) did not prevent the adrenalectomy-induced restoration of both growth hormone and prolactin receptors. The resulting high serum testosterone level did not reduce binding to growth hormone receptors in control rats over the 3 day period, and caused no further decrease in diabetic rats. However, binding to prolactin receptors was reduced by $47 \%$ in control animals with no further loss in diabetic animals $(p<0.001)$. Adrenalectomy prevented the loss of prolactin receptors in both testosterone-treated and diabetic rats. These results indicate that, whether or not the rise in testosterone of adrenal origin contributes to the receptor loss in diabetes, the effect also depends on another factor of adrenal origin.

Key words: Growth hormone receptor, prolactin receptor, somatomedin- $C$, insulin-like growth factor-I, diabetes, adrenalectomy, testosterone.

no effect on testosterone levels in diabetes, adrenalectomy prevented the rise caused by diabetes, implying that the testosterone was of adrenal origin [6].

Testosterone has been widely documented as having a suppressive effect on PRL receptors [7-11], and we have previously reported that testosterone administration decreases the number of PRL receptors in the livers of both normal and diabetic rats [2]. In contrast to prolactin receptors, little is known about the regulation of GH receptors in rat liver by sex steroids, except that livers from female animals are known to have more receptor sites that those from males when measured in either whole hepatocytes [12] or microsomal membrane preparations $[1,13]$.

If androgens suppress $\mathrm{GH}$ as well as PRL receptors in female rat liver, the increase in adrenal androgen production seen in diabetes might be responsible for the loss of both receptor types and of SM-C/IGF-I observed in earlier studies. 
Table 1. Weight changes, serum glucose and insulin levels in adrenalectomised and sham-operated rats

\begin{tabular}{llllll}
\hline & \multicolumn{2}{l}{ Sham-operated rats } & \multicolumn{2}{l}{ Adrenalectomised rats } \\
\cline { 2 - 3 } & $\begin{array}{l}\text { Normal } \\
(n=7)\end{array}$ & $\begin{array}{l}\text { Diabetic } \\
(n=8)\end{array}$ & & $\begin{array}{l}\text { Normal } \\
(n=7)\end{array}$ & $\begin{array}{l}\text { Diabetic } \\
(n=8)\end{array}$ \\
\hline $\begin{array}{l}\text { Weight } \\
\text { change }(\mathrm{g})\end{array}$ & $+9.7 \pm 3.1$ & $-5.3 \pm 8.0^{\mathrm{c}}$ & $+8.1 \pm 5.7$ & $-1.0 \pm 8.7^{\mathrm{a}}$ \\
$\begin{array}{l}\text { Serum } \\
\text { glucose } \\
\text { (mmol/1) }\end{array}$ & $8.5 \pm 3.8$ & $34.8 \pm 3.1^{\mathrm{c}}$ & $7.6 \pm 2.1$ & $27.2 \pm 4.9^{\mathrm{c}, \mathrm{d}}$ \\
$\begin{array}{l}\text { Serum } \\
\text { insulin } \\
\text { (mU/1) }\end{array}$ & $34.6 \pm 9.2$ & $16.0 \pm 1.1^{\mathrm{c}}$ & $24.9 \pm 5.4^{\mathrm{b}}$ & $16.1 \pm 2.5^{\mathrm{c}}$ \\
\hline
\end{tabular}

Values are mean $\pm \mathrm{SD}$

${ }^{\mathrm{a}} p<0.01,{ }^{\mathrm{b}} p<0.005,{ }^{\mathrm{c}} p<0.001$. Comparisons with sham-operated non-diabetic animals

${ }^{d} p<0.001$. Comparisons with sham-operated diabetic animals
Table 2. Serum testosterone in adrenalectomised and sham-operated rats with and without testosterone treatment

\begin{tabular}{|c|c|c|c|c|}
\hline & \multicolumn{4}{|c|}{ Serum testosterone $(\mathrm{nmol} / \mathrm{l})$} \\
\hline & \multicolumn{2}{|c|}{ Sham-operated rats } & \multicolumn{2}{|c|}{ Adrenalectomised rats } \\
\hline & Normal & Diabetic & Normal & Diabetic \\
\hline Control rats & $\begin{array}{l}2.45 \pm 0.96 \\
(n=9)\end{array}$ & $\begin{array}{l}5.30 \pm 1.60^{\mathrm{a}} \\
(n=14)\end{array}$ & $\begin{array}{l}2.49 \pm 1.62 \\
(n=12)\end{array}$ & $\begin{array}{l}2.17 \pm 0.76 \\
(n=14)\end{array}$ \\
\hline $\begin{array}{l}\text { Testosterone- } \\
\text { treated rats }\end{array}$ & $\begin{array}{l}74 \pm 19 \\
(n=4)\end{array}$ & $\begin{array}{l}77 \pm 21 \\
(n=6)\end{array}$ & $\begin{array}{l}87 \pm 30 \\
(n=6)\end{array}$ & $\begin{array}{l}106 \pm 32 \\
(n=7)\end{array}$ \\
\hline
\end{tabular}

Values are means $\pm S D$. Diabetic rats received streptozotocin $(100 \mathrm{mg} / \mathrm{kg}) 6$ days prior to killing

${ }^{a} p<0.001$ Comparison with sham-operated non-diabetic animals
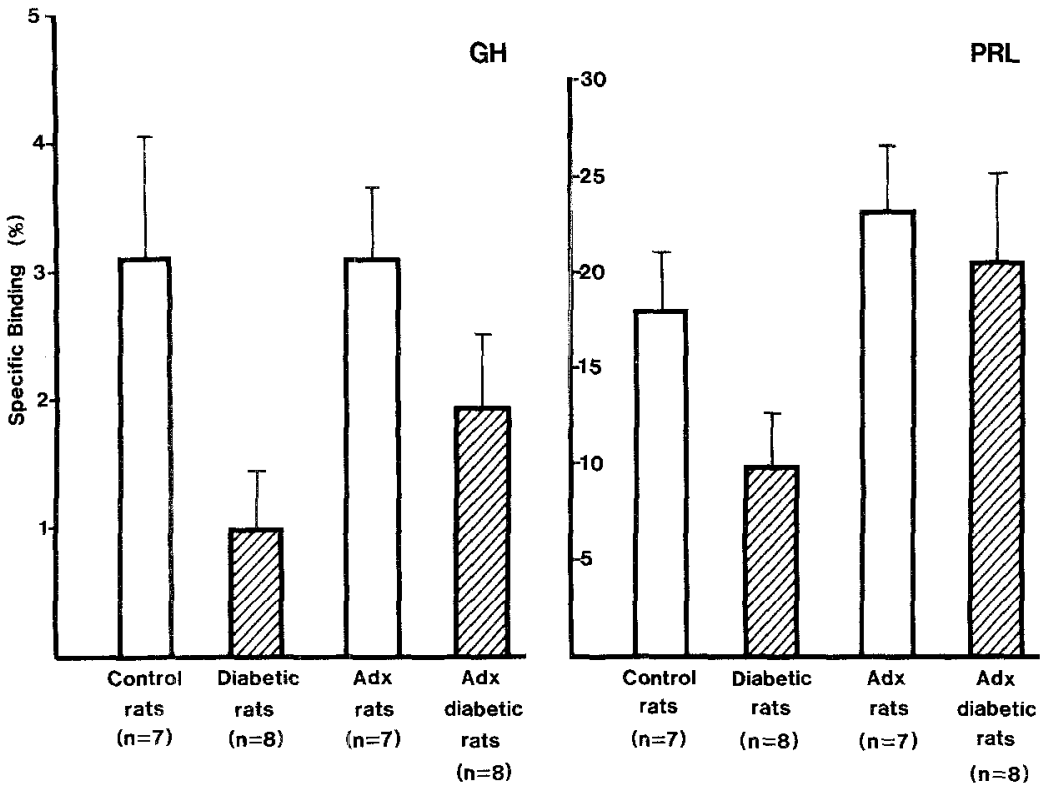

Fig. 1. Effect of adrenalectomy (Adx) on binding of bovine GH and ovine PRL tracers to liver microsomal membranes from non-diabetic $(\square)$ and diabetic (Z7) female rats. Data are expressed as mean \pm SD. Significant differences refer to a comparison with the control group, with diabetic rats (GH and PRL) $p<$ 0.001 , Adx rats $(\mathrm{GH})$ N.S., Adx rats (PRL) $p<0.05$, Adx diabetic rats $(\mathrm{GH}) p<0.01$ and Adx diabetic rats (PRL) N.S.
To investigate this hypothesis, we studied the effects of adrenalectomy and the effects of pharmacologically increasing the serum testosterone concentration on hepatic GH and PRL receptors and serum SM-C/IGF-I levels in normal and diabetic rats.

\section{Materials and methods}

\section{Procedures}

Female Wistar-Furth rats weighing $120-140 \mathrm{~g}$ were housed under standardised lighting conditions (light on from 07.30 to $19.30 \mathrm{~h}$ ) and fed standard rat cubes with water ad libitum. Each experimental group contained six or seven animals. In the initial experiments designed to test the effects of androgens, rats were subcutaneously given a mixture of testosterone propionate, phenyl propionate and isocaproate (Sustanon, Organon, Sydney, Australia), $1 \mathrm{mg} /$ day for 12 days, commencing 5 days before streptozotocin treatment. Diabetes was in- duced by streptozotocin, $100 \mathrm{mg} / \mathrm{kg}$ (Calbiochem, La Jolla, California, USA), freshly dissolved in $0.1 \mathrm{~mol} / 1 \mathrm{Na}$ citrate buffer $\mathrm{pH} 4.0$ and administered by tail vein injection. Controls received buffer alone. To study the role of the adrenals, rats were adrenalectomised bilaterally 3 days after streptozotocin treatment. Non-adrenalectomised control rats were sham operated.

In a later protocol, testosterone-treated rats were implanted with testosterone-filled silastic capsules at the time of adrenalectomy or sham operation. These capsules were made from silastic tubing (No.602-265, Dow Corning, Midland, Michigan, USA) with $1.6 \mathrm{~mm}$ internal diameter and $2.4 \mathrm{~mm}$ external diameter). Capsules were filled with testosterone (Sigma, St. Louis, Missouri, USA) to a length of $5 \mathrm{~mm}$. On day 6 following streptozotocin treatment, rats were anaesthetised with Ketalar, $1 \mathrm{ml} / \mathrm{kg}$ (Parke-Davis, Sydney, Australia), blood was collected by cardiac puncture, and the livers were removed and stored at $-80^{\circ} \mathrm{C}$ until used for membrane preparation.

\section{Binding studies}

Liver microsomal membranes were prepared by differential centrifugation as previously described [14]. GH and PRL receptors were mea- 
Table 3. Binding to GH and PRL receptors in adrenalectomised and sham-operated rats with and without testosterone implants

\begin{tabular}{lll}
\hline & $\begin{array}{l}\text { Specific } \\
\text { GH Binding } \\
\text { (\% of Total) }\end{array}$ & $\begin{array}{l}\text { Specific } \\
\text { PRL Binding } \\
\text { (\% of Total) }\end{array}$ \\
\hline $\begin{array}{l}\text { Control rats } \\
\text { Normal } \\
(n=10)\end{array}$ & $3.02 \pm 0.83$ & $22.2 \pm 8.0$ \\
$\begin{array}{l}\text { Adrenalectomised } \\
(n=12)\end{array}$ & $3.10 \pm 0.69$ & $25.7 \pm 4.5$ \\
$\begin{array}{l}\text { Diabetic } \\
(n=14)\end{array}$ & $1.01 \pm 0.42^{\mathrm{c}}$ & $10.0 \pm 2.6^{\mathrm{c}}$ \\
$\begin{array}{l}\text { Adrenalectomised } \\
- \text { Diabetic } \\
(n=11)\end{array}$ & $1.78 \pm 0.57^{\mathrm{b}, \mathrm{d}}$ & $22.0 \pm 5.5^{\mathrm{e}}$ \\
$\begin{array}{l}\text { Testosterone-treated rats } \\
\text { Normal } \\
(n=4)\end{array}$ & $2.45 \pm 0.84$ & $14.2 \pm 2.5^{\mathrm{a}}$ \\
$\begin{array}{l}\text { Adrenalectomised } \\
(n=6)\end{array}$ & $3.28 \pm 1.07$ & $22.8 \pm 7.1$ \\
$\begin{array}{l}\text { Diabetic } \\
(n=6)\end{array}$ & $0.73 \pm 0.56^{\mathrm{c}}$ & $9.8 \pm 4.0^{\mathrm{c}}$ \\
$\begin{array}{l}\text { Adrenalectomised } \\
\text { Diabetic } \\
(n=7)\end{array}$ & $1.90 \pm 0.76^{\mathrm{b}, \mathrm{d}}$ & $21.6 \pm 3.1^{\mathrm{e}}$ \\
\hline $\begin{array}{l}\text { Dic } \\
\text { Din }\end{array}$ & & \\
\hline
\end{tabular}

Values are expressed as mean $\pm \mathrm{SD}$

${ }^{\mathrm{a}} p<0.01,{ }^{\mathrm{b}} p<0.05,{ }^{\mathrm{c}} p<0.001$. Comparison with normal control animals

${ }^{\mathrm{d}} p<0.05,{ }^{\mathrm{e}} p<0.001$. Comparison with corresponding diabetic animals

Table 4. Effect of adrenalectomy on serum SM-C/IGF-I levels in control and diabetic rats

\begin{tabular}{ll}
\hline & $\begin{array}{l}\text { SM-C/IGF-I } \\
(\mathrm{U} / \mathrm{ml})\end{array}$ \\
\hline $\begin{array}{l}\text { Control rats } \\
(n=7)\end{array}$ & $0.68 \pm 0.09$ \\
$\begin{array}{l}\text { Adrenalectomised rats } \\
(n=7)\end{array}$ & $0.58 \pm 0.09^{\mathrm{a}}$ \\
$\begin{array}{l}\text { Diabetic rats } \\
(n=8)\end{array}$ & $0.18 \pm 0.10^{\mathrm{b}}$ \\
$\begin{array}{l}\text { Adrenalectomised } \\
\text { - Diabetics } \\
(n=8)\end{array}$ & $0.28 \pm 0.10^{\mathrm{b}, \mathrm{c}}$ \\
\hline
\end{tabular}

Values are expressed as mean $\pm \mathrm{SD}$

a $p<0.05$, b $p<0.001$. Comparison with control animals

${ }^{c} p<0.05$. Comparison with diabetic animals

sured on $200 \mu \mathrm{g}$ of membrane protein, using bovine $\mathrm{GH}(\mathrm{bGH})$ and ovine PRL (oPRL) respectively as radioligands as reported earlier [1, 2]. Briefly, for either receptor type incubations were performed at $22^{\circ} \mathrm{C}$ in $1.5 \mathrm{ml}$ polystyrene centrifuge tubes for $16 \mathrm{~h}$ in a final volume of $0.3 \mathrm{ml}$ of Tris- $\mathrm{HCl}(25 \mathrm{mmol} / \mathrm{l}), \mathrm{CaCl}_{2}(10 \mathrm{mmol} / \mathrm{l})$ buffer containing $0.1 \%$ bovine albumin, $\mathrm{pH} 7.4$. Tracer hormone, iodinated using chloramine $T$ to a specific activity of approximately $100 \mathrm{Ci} / \mathrm{g}$, was present at $10 \mathrm{nCi}(100 \mathrm{pg}) /$ tube. At the end of the incubation period, membranes were pelleted by centrifugation for $7 \mathrm{~min}$ at $7,000 \mathrm{~g}$ (Beckman Microfuge, Beckman Instruments Inc., Palo Alto, California, USA), washed in $1 \mathrm{ml}$ of cold incubation buffer, and the tips of the tubes containing the pellets were cut off and counted in a gamma counter (LKB-Wallac Multigamma, Turku, Finland).

Non-specific binding measured in the presence of unlabelled hormone $(0.5 \mu \mathrm{g})$ was typically $4 \%$ of total radioactivity for bGH tracer and $6 \%$ of total radioactivity for oPRL tracer. Although the nonspecific binding of bGH tracer was high relative to the specific binding, this figure is comparable to that seen in other published studies of bGH binding to microsomal membranes [1, 14], homogenates [5] and hepatocyte pellets [12]. The bGH for iodination (S-32-35) was donated by Dr. M.Sonenberg, Memorial Sloan-Kettering Cancer Center, New York, USA. Iodination grade oPRL (I-1) was provided by the National Hormone and Pituitary Program, National Institute of Arthritis, Diabetes, Digestive and Kidney Diseases, Bethesda, Maryland, USA. Specificity studies validating the use of these ligands for GH and PRL receptor measurement have been reported previously [1, 2].

\section{Hormone assays}

Testosterone was measured using Bio-RIA (Louisville, Kentucky, USA) $\mathrm{I}^{125}$-Testosterone direct (no extraction) Covalent Coat Tubes Radioimmunoassay kit. Serum oestradiol was measured after ether extraction by radioimmunoassay using $16 \alpha$-[ $\left[1^{125}\right]$-iodoestradiol (New England Nuclear, Boston, Massachusetts, USA) and antiserum (Endocrine Sciences, Tarzana, California, USA). Due to the large sample requirement, measurements were made on pooled specimens. Insulin was measured using the Insulin Radioimmunoassay kit from BioRIA. Somatomedin-C levels were determined on acid-ethanol extracted serum samples [16] by specific radioimmunoassay using antiserum $\operatorname{Tr} 4$ as described previously [17]. Glucose was measured using glucose oxidase and peroxidase.

\section{Statistical analysis}

Differences between control and treated animals were evaluated using Duncan's multiple range test [18] after pooling variances by analysis of variance.

\section{Results}

Weight changes and serum glucose and insulin levels in the diabetic and adrenalectomised animals are shown in Table 1. Adrenalectomy did not alter the effect of diabetes on body weight change or serum insulin levels, although it appeared to marginally ameliorate the hyperglycaemia. There was a $66 \%$ decrease in bGH tracer binding $(p<0.001)$ and a $56 \%$ decrease in oPRL binding $(p<0.001)$ in diabetic rats compared to normal rats (Fig. 1). This was accompanied by a 2.2 -fold increase in serum testosterone levels (Table 2 ) with no change in the mean oestradiol level (control: $204 \mathrm{pmol} / 1$; diabetic: $270 \mathrm{pmol} / \mathrm{l}$ ). Adrenalectomy had no effect on GH binding in normal rats, but there was a slight increase $(p<$ 0.05 ) in binding of PRL. Adrenalectomy 3 days after the induction of diabetes completely restored the binding of oPRL to control levels, whereas bGH binding was only partially restored $(p<0.01$ compared with control rats and $p<0.01$ compared to diabetic rats). This was accompanied by the return of serum testosterone levels to control values (Table 2). The mean serum oestradiol level was reduced by over $60 \%$ by adrenalectomy to $79 \mathrm{pmol} / 1$, with diabetes causing no further change (71 pmol/1). 


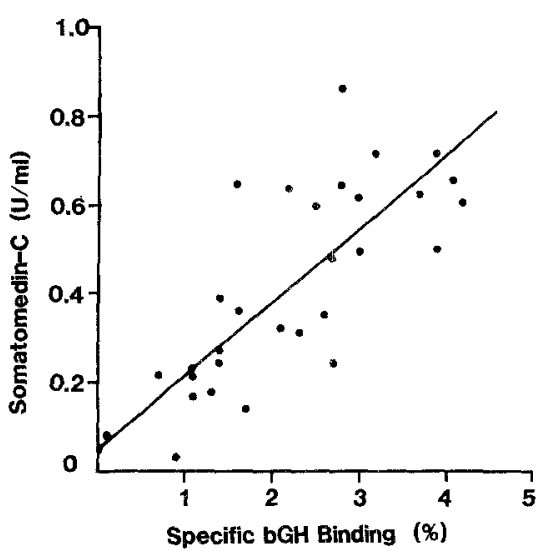

Fig. 2. Association between specific binding of tracer bovine GH to liver microsomal membranes and serum SM-C/IGF-I levels in the group of animals referred to in Fig. 1. The correlation coefficient $(r=0.759)$ was highly significant $(p<0.0001)$

Since the changes in serum testosterone levels were consistent with the involvement of testosterone in the modulation of GH and PRL receptors, the effect of testosterone was studied directly by giving 12 daily injections of a commercial preparation (Sustanon, $1 \mathrm{mg}$ / day). Testosterone reduced specific binding to $\mathrm{GH}$ sites in livers from normal animals $(3.85 \pm 0.47 \%$ of total, $n=6)$ by $40 \%(p<0.001)$, while diabetes caused the previously observed $67 \%$ decrease in binding $(p<0.001)$. The effects of diabetes and testosterone appeared to be additive, as the combined effect was a further decrease in binding of $72 \%(p<0.001)$ compared to testosterone alone, and a further decrease of $49 \%(p<0.01)$ compared to diabetes alone.

As in our earlier study [2], the diabetes and testosterone effects on PRL binding interacted in a similar way. Diabetes reduced specific binding (17.8 $\pm 4.3 \%$ of total, $n=6)$ by $57 \%(p<0.001)$, testosterone by $64 \%(p<$ $0.001)$, and diabetes + testosterone by $75 \%(p<0.001)$ compared with normal animals. As seen for bGH binding, the effects of diabetes and testosterone appeared to be additive. However, due to the effect of large variance in the normal group on the pooled variance for all groups, the decrease in binding due to diabetes + testosterone, when tested using Duncan's multiple range test, was barely significant compared to diabetes alone $(p=0.05)$ and not significant compared to testosterone alone $(p>0.05)$. When re-tested by Student's t-test, however, the combined effect of diabetes and testosterone was indeed significantly greater than that of diabetes $(p<0.01)$ or testosterone $(p<0.001)$ alone. Mean $( \pm \mathrm{SD})$ testosterone levels in normal animals were $2.1 \pm 0.6 \mathrm{nmol} / 1$, increasing to $5.8 \pm 0.4 \mathrm{nmol} / 1$ in diabetes, while in testosterone-treated animals the mean value was $33.2 \pm 1.6 \mathrm{nmol} / 1$ for non-diabetic and $29.8 \pm$ $2.3 \mathrm{nmol} / 1$ for diabetic rats.

To test the effects of simultaneous testosterone administration and adrenalectomy, testosterone filled capsules were implanted at the time of adrenalectomy.
Since maximal loss of hGH binding had previously been shown to require 12 days of testosterone treatment [7], a high testosterone concentration was used in this experiment in an attempt to produce a significant response in the 3-day experimental period. The implants resulted in serum testosterone levels between 70 and $100 \mathrm{nmol} / 1$ in all rats (Table 2). Despite this high level of testosterone, the binding to GH receptors in non-adrenalectomised, non-diabetic rats was decreased by only $20 \%$ in the 3 days of implantation and in diabetic rats by approximately $30 \%$ (Table 3 ) compared with animals not receiving testosterone. This modest effect of testosterone probably reflects the short duration of treatment [7]. Testosterone treatment did not prevent the restoration of $\mathrm{GH}$ receptors in diabetic rats following adrenalectomy, suggesting that the adrenal-mediated changes in diabetes were not due to increased testosterone production.

However, testosterone treatment decreased PRL binding by $47 \%$ in non-adrenalectomised, non-diabetic animals, with no further drop in diabetic animals $(p<$ 0.001 ) (Table 3). Adrenalectomy prevented this testosterone-induced loss of PRL binding in non-diabetic rats, as well as the diabetes-induced loss of binding. Despite the high testosterone levels in rats with implants, an increase in PRL receptors following adrenalectomy was still seen in diabetic rats.

Changes in serum SM-C/IGF-I levels due to diabetes were observed to parallel closely those in GH receptors (Table 4), with the decrease in diabetes being partly blocked by adrenalectomy. Similar results were seen in animals with testosterone implants (data not shown). The relationship between $\mathrm{GH}$ receptors and SM-C/ IGF-I levels in individual animals is shown in Fig. 2. A highly significant association was seen $(r=0.759, p<$ 0.0001 ), while between the PRL binding and SM-C/ IGF-I levels there was a somewhat weaker association $(r=0.484, p<0.001)$.

\section{Discussion}

It has been reported that rats with chronic diabetes produced by streptozotocin show an abnormal regulation of the factors that control adrenal steroid regulation and metabolism [19]. These rats have adrenal hypertrophy with high resting levels of plasma corticosterone and an increased response to stress with changes in the feedback response [20]. More recently, Leaming et al. [6] have shown that the increase in serum testosterone that we had observed in diabetes [2] was due to increased production of androgens by the adrenals. The role of testosterone as a regulator of PRL receptors in rat liver is well documented [7-11]. In males, binding to PRL receptors is increased by castration and decreased by testosterone administration $[7,10]$. In females, testosterone treatment decreases, although not to male levels, PRL binding $[8,9]$. 
Regulation of rat liver GH receptors by testosterone has not been documented, although it has been reported that females have more receptors than males $[1,12$, 13]. Our studies confirm that testosterone decreases PRL receptors, and they establish a similar role for testosterone on GH binding in the livers of female rats. Very strong negative correlations are seen between testosterone and both GH $(r=0.706, p<0.0001)$ and PRL ( $r=0.744, p<0.0001$ ) binding.

The decreased PRL binding in rat liver caused by androgen treatment has been reported to be due to the direct action of testosterone on the liver $[8,9]$. However, the present study suggests that the effects of both testosterone and diabetes on liver PRL receptors and, to a lesser extent, on $\mathrm{GH}$ receptors are mediated by the adrenals. Whether the effects of diabetes are due to changing testosterone levels, or the regulatory pathways for testosterone and diabetes are quite separate, remains unresolved, since both effects were abolished by adrenalectomy. However, further suppression of both $\mathrm{GH}$ and PRL receptors by diabetes in animals which had received testosterone implants indicates that there are important additional regulatory mechanisms in the diabetic animal. Treatment of diabetic rats with anti-androgens may answer the question whether testosterone plays any part at all.

From these studies it is concluded that the regulatory effect of insulin on hepatic GH and PRL receptors is mediated, at least in part, via the adrenal glands. The partial restoration of SM-C/IGF-I levels in diabetic rats following adrenalectomy indicates an adrenal component also in the regulation of this peptide, while the failure of adrenalectomy to cause complete reversal of SMC/IGF-I levels (or of GH receptors) suggests an additional suppressive factor, perhaps related to the relative nutritional deficiency of diabetic rats [21]. One regulatory factor known to affect both receptor types and SM-C/IGF-I is GH itself. GH secretion is decreased in both fasting [22] and diabetes [23], conditions where hepatic GH and PRL receptors, and serum SM-C/IGF-I levels $[4,21,24]$, are diminished. Our results could be explained if an adrenal factor, perhaps a catecholamine, were found to be a physiological regulator of pituitary GH secretion. The demonstration that $\alpha$-adrenergic blockade enhances $\mathrm{GH}$ release, possibly by inhibiting hypothalamic somatostatin release [25], supports this hypothesis. If this is so, the decrease in $\mathrm{GH}$ secretion seen in diabetes [23] would be dependent upon increased adrenal catecholamine secretion, and should be reversed by adrenalectomy.

Changes in GH secretion would directly affect both GH and PRL receptor levels and hepatic SM-C/IGF-I production. $\mathrm{GH}$ administration is known to induce PRL receptors in the livers of hypophysectomised rats [26], and recent studies from this laboratory have shown that both GH and PRL receptors are also induced by $\mathrm{GH}$ in intact animals of both sexes [27,28]. With regard to SM-C/IGF-I, this peptide has long been recognised as being under $\mathrm{GH}$ control [29]. In reports from this laboratory, a highly significant association was seen between GH secretory spikes and serum SM-C/IGF-I levels integrated over a 5-hour period [17], and in studies of SM-C/IGF-I release by rat hepatocytes in primary culture, both the GH status of the donor animal and the addition of $\mathrm{GH}$ in vitro have been found to modulate the rate of growth factor release [30].

Receptors for GH may also be closely involved in the regulation of SM-C/IGF-I synthesis, as indicated by the close correlation observed between hepatic $\mathrm{GH}$ binding and serum SM-C/IGF-I levels in hypophysectomised rats in which both GH receptors and SM-C/ IGF-I were restored by GH infusion [28]. In the present study we again observed a significant relationship between GH receptors and serum SM-C/IGF-I. In particular, the partial restoration of $\mathrm{GH}$ receptors after adrenalectomy of diabetic rats was closely paralleled by an increase in SM-C/IGF-I. Further testing of the hypotheses resulting from these experiments will require detailed measurements of the combined effects of diabetes, adrenalectomy and testosterone treatment on GH and PRL secretory dynamics. Since both hormones are secreted in a pulsatile manner $[31,32]$ and are affected by stress [32,33], measurements in random serum samples are unlikely to provide meaningful information. Therefore, resolution of these questions will require serial sampling from chronically cannulated, unrestrained rats. These studies should help to elucidate the exact role of insulin, androgens and catecholamines in modulating GH and PRL secretion and in the maintenance of hepatic receptor and serum SM-C/IGF-I levels.

Acknowledgements. These studies were supported by the National Health and Medical Research Council, Australia, and the Kellion Diabetes Foundation. The gifts of bovine GH from Dr. M. Sonenberg and other pituitary hormones from the National Hormone and Pituitary Program, National Institute of Arthritis, Diabetes, Digestive and Kidney Diseases are gratefully acknowledged. We wish to thank Mr. C. Howe for the serum oestradiol estimations and Ms. T. Meucci for typing this manuscript.

\section{References}

1. Baxter RC, Bryson JM, Turtle JR (1980) Somatogenic receptors of rat liver: regulation by insulin. Endocrinology 107: 1176-1181

2. Baxter RC, Bryson JM, Turtle JR (1981) Changes in rat liver prolactin binding sites in diabetes are sex dependent. Metabolism 30: 211-215

3. Klapper DG, Svoboda ME, Van Wyk JJ (1983) Sequence analysis of somatomedin-C: confirmation of identity with insulin-like growth factor I. Endocrinology 112: 2215-2217

4. Baxter RC, Brown AS, Turtle JR (1979) Decrease in serum receptor-reactive somatomedin in diabetes. Horm Metab Res 11: 216-220

5. Maes M, Ketelslegers JM, Underwood LE (1983) Low plasma somatomedin-C in streptozotocin-induced diabetes mellitus. Correlation with changes in somatogenic and lactogenic liver binding sites. Diabetes 32: 1060-1069

6. Leaming AB, Mathur RS, Levine JH (1982) Increased plasma tes- 
tosterone in streptozotocin-diabetic female rats. Endocrinology 111: $1329-1333$

7. Herington AC, Burger HG, Veith NM (1976) Binding of human growth hormone to hepatic lactogenic binding sites: regulation by oestrogens and androgens. J Endocrinol 70:473-484

8. Sherman BM, Stagner JI, Zamudio R (1977) Regulation of lactogenic hormone binding in rat liver by steroid hormones. Endocrinology 100: 101-107

9. Kelly PA, Le Blanc G, Ferland L, Labrie F, De Lean A (1977) Androgen inhibition of basal and estrogen-stimulated prolactin binding in rat liver. Mol Cell Endocrinol 9: 195-204

10. Aragona C, Bohnet HG, Friesen HG (1976) Prolactin binding sites in the male rat liver following castration. Endocrinology 99 : 1017-1022

11. Barkey RJ, Shani J, Zahav M, Amit T, Youdin MBH (1981) Effect of prolactin and prostaglandins on the stimulation of prolactin binding sites in the male rat liver. Mol Cell Endocrinol 21: $129-138$

12. Ranke MB, Stanley CA, Tenore A, Rodbard D, Bongiovanni AM, Parks JS (1976) Characterization of somatogenic and lactogenic binding sites in isolated rat hepatocytes. Endocrinology 99 : 1033-1045

13. Maes M, De Hertogh R, Watrin-Granger $P$ and Ketelslegers JM (1983) Ontogeny of liver somatotropic and lactogenic binding sites in male and female rats. Endocrinology 113: 1325-1332

14. Baxter RC, Turtle JR (1978) Regulation of hepatic growth hormone receptors by insulin. Biochem Biophys Res Commun 84: 350-357

15. Posner BI, Patel B, Vezinhet A and Charrier J (1980) Pituitarydependent growth hormone receptors in rabbit and sheep liver. Endocrinology 107: 1954-1958

16. Daughaday WH, Mariz IK, Blethen SL (1980) Inhibition of access of bound somatomedin to membrane receptor and immunobinding site: a comparison of radioreceptor and radioimmunoassay of somatomedin in native and acid-ethanol extracted serum. J Clin Endocrinol Metab 51: 781-788

17. Baxter RC, Zaltsman Z, Oliver JR, Willoughby JO (1983) Pulsatility of immunoreactive somatomedin-C in chronically cannulated rats. Endocrinology 113: 729-734

18. Braning JL, Kintz BL (1968) Computational handbook of statistics. Scott, Foresman, Glenview, Illinois, p 115

19. L'Age M, Langholz J, Fechner W, Salzmann H (1974) Disturbances of the hypothalamo-hypophysical-adrenocorticol system in the alloxan diabetic rat. Endocrinology 95: 760-765

20. De Nicola AF, Fridman O, Del Castillo EJ, Foglia VG (1977) Abnormal regulation of adrenal function in rats with streptozotocin diabetes. Horm Metab Res 9: 469-473

21. Baxter RC, Bryson JM, Turtle JR (1981) The effect of fasting on liver receptors for prolactin and growth hormone. Metabolism 30: $1086-1090$
22. Tannenbaum GS, Epelbaum J, Colle E, Brazeau P, Martin J (1978) Antiserum to somatostatin reverses starvation-induced inhibition of growth hormone but not insulin secretion. Endocrinology 102: 1909-1914

23. Tannenbaum GS (1981) Growth hormone secretory dynamics in streptozotocin diabetes. Evidence for a role for endogenous circulating somatostatin. Endocrinology 108: 76-82

24. Maes M, Underwood LE, Ketelslegers J-M (1983) Plasma somatomedin- $\mathrm{C}$ in fasted and refed rats: close relationship with changes in liver somatogenic but not lactogenic binding sites. J Endocrinol 97: 243-252

25. Chihara K, Minamitani N, Kagi H, Kodama H, Kita T, Fujita T (1984) Noradrenergic modulation of human pancreatic growth hormone-releasing factor (hpGHRF 1-44)-induced growth hormone release in conscious male rabbits: Involvement of endogenous somatostatin. Endocrinology 114: 1402-1406

26. Norstedt G (1982) A comparison between the effects of growth hormone on prolactin receptors and estrogen receptors in rat liver. Endocrinology 110: 2107-2112

27. Baxter RC, Zaltsman Z, Turtle JR (1984) Rat growth hormone, but not prolactin, induces both growth hormone and prolactin receptors in female rat liver. Endocrinology 114: 1893-1901

28. Baxter RC, Zaltsman Z (1984) Induction of hepatic receptors for growth hormone $(\mathrm{GH})$ and prolactin by $\mathrm{GH}$ infusion is sex independent. Endocrinology 115: 1009-1014

29. Daughaday WH, Heins JN, Srivastava L, Hammer C (1968) Sulfation factor: Studies of its removal from plasma and metabolic fate in cartilage. J Lab Clin Med 72: 803-812

30. Scott CD, Martin JL, Baxter RC (1985) Rat hepatocyte insulin-like growth factor I and binding protein: Effect of growth hormone in vitro and in vivo. Endocrinology 116: 1102-1107

31. Tannenbaum GS, Martin JB (1976) Evidence for an endogenous ultradian rhythm governing growth hormone secretion in the rat. Endocrinology 98: 562-570

32. Terry LC, Saunders A, Audet J, Willoughby JO, Brazeau P, Martin JB (1977) Physiologic secretion of growth hormone and prolactin in male and female rats. Clin Endocrinol 6:19s-28s

33. Takahashi K, Daughaday WH, Kipnis DM (1971) Regulation of immunoreative growth hormone secretion in male rats. Endocrinology $88: 909-917$

Received: 2 January 1985

and in revised form: 21 November 1985

Dr. Robert C. Baxter

Department of Endocrinology

Royal Prince Alfred Hospital

Camperdown, NSW 2050

Australia 